Vol. 38(1), pp. 60-70, June 2019

ISSN 1821-536X (print)

ISSN 2619-8789 (electronic)
Tanzania Journal of Engineering and Technology

Copyright $\odot 2019$ College of Engineering and

Technology, University of Dar es Salaam

Full Length Research Paper

\title{
Linking Quality Management Practices with Performance of Manufacturing Industries in Tanzania
}

\author{
Mussa I. Mgwatu \\ Department of Mechanical and Industrial Engineering, University of Dar es Salaam \\ P.O. Box 35131, Dar es Salaam, Tanzania \\ E-mail: mgwatu@udsm.ac.tz
}

\begin{abstract}
Local products of manufacturing industries in Tanzania are subjected to intense competition in the markets. Product quality is one of key factors that play a considerable role for manufacturing industries to win the competitive advantage. This paper attempts to analyse the extents of quality management practices $(Q M P)$ and manufacturing performance (MP) as well as to examine the linkage between practices and performance. Data was collected from seventy-eight (78) manufacturing industries in Dar es Salaam region using questionnaires comprising of both single-item and multi-item questions. Descriptive statistics was used to quantify the extent of quality management practices and manufacturing performance (MP) of the industries. Factor analysis was used to reduce the scale items of QMP and MP into few underlying factors representing the items without loss of information. As a consequence, four QMP and two MP factors were identified. A correlation analysis was used to evaluate the effect of QMP on the performance of manufacturing industries. The findings show that most of manufacturing industries in Tanzania are large in scale and owned by private companies. Among these industries, many of them are dealing with food, beverage and tobacco products. The extent of quality management practices and manufacturing performance are favourable. Further to that, quality management practices mainly quality commitment significantly correlates with both operational and financial performance. This can be seen as a positive indication of the top management commitment in quality issues throughout the supply chain in supporting customer satisfaction, competitive advantage, flexibility in production quantity and overall product quality. Thus, local manufacturing industries should utilise the quality management and performance strengths to produce high-quality products that will penetrate into the markets. In addition, enforcement on the implementation of quality management tools and methods is required for the purpose of realising reasonable operational and financial performance while winning the competitive advantage.
\end{abstract}

Keywords: Correlation analysis; Factor analysis; Manufacturing industries; Performance; Quality management.

\section{INTRODUCTION}

The manufacturing sector plays a significant role in the Tanzania's economy and continues to be one of the major sources of government revenue. However, the open market and investment policies have subjected Tanzania's manufacturing industries to intense competition stress such that the trend of manufacturing imports is increasing while the trend of manufacturing exports is declining. For instance, the study by MIT (2001) revealed that manufacturing imports of fabricated 
metals and machinery represent $51 \%$ of all manufacturing imports. On the other hand, manufacturing exports of fabricated metals and machinery represent only $4 \%$ of all manufacturing exports. Tanzania has identified nine categories of manufacturing industries including (CTI/DI, 2000): (i) Food, beverage and tobacco; (ii) Textiles, clothing, leather and footwear; (iii) Wood and wooden products, excluding furniture activities; (iv) Paper and paper products; (v) Chemicals, petroleum, rubber and plastics; (vi) Non-metallic mineral products; (vii) Basic metal products; (viii) Fabricated metals, machinery and equipment; and (ix) Other manufacturing industries.

In today's intense competition forces, manufacturing industries have dedicated more efforts to quality management in order to ensure that they produce highquality products which can penetrate into the market. Quality management requires involvement from internal functions and external partners. Employees should treat themselves as internal customers. Otherwise if the internal customer is not satisfied, the product value creation for the external customer is also difficult. Quality management can improve operating efficiency by reducing defect rate, scrap rate, and the occurrence of rework thus improve customers' satisfaction and eventually company's overall performance. Adam et al. (2001) listed different tools which are used in determining the extent of quality management practices. These are the use of benchmarking, six sigma, inspection, quality circles, seven basic tools, simplify the products, using standard componets, process improvement, design of quality into the products, training in quality management and control, modular design of component parts, considering of quality of raw materials from supplier and top management involvement in quality goals. A company's performance measurement system drives its behaviour to achieve its strategic objectives. Additionally, Adam et al. (2001) highlighted performance measures for manufacturing industries include customer satisfaction, return on assets, overall product quality, overall competitive position, overall customer service level, market share, sales growth, and profit growth.

Several researchers have reported on quality management practices and their relationship with firms' performance. Santos-Vijande and Alvarez-Gonzalez (2007) developed an instrument to provide an evidence of the relationship between quality management practices and measures of business performance. The findings revealed that the adoption of total quality management practices allows firms to attain competitive advantage and in consequence outperform their competitors. Kannan and Tan (2005), Zakuan et al. (2007), and Jaafreh (2013) examined the extent to which quality management practices and organizational performance are correlated and how they impact on organizational performance. From the managerial perspective, the results showed that there is a strong relationship between quality management dimensions and organization performance; that the commitment to quality has great effect on the performance of the organization. According to Nguyen et al. (2018), the impact of quality management practices on sustainability performance are different across groups with different quality management experience time, type of industry and firm size. Sabella et al. (2014), Sayyad (2017), and Keinan and Karugu (2018) examined the philosophy of total quality management (TQM) practices and relationship to organizational performance. It was found that total quality management variables positively relate to firm performance.

Some researchers have moved another step forward for a new study area of supply chain quality management. Lin et al. 
(2005), Kuei et al. (2008), Talib et al. (2010), and Vanichchinchai and Igel (2011) investigated on the correlation of supply chain quality management and organization performance. It was found that quality management has direct positive linkage with supply chain management and on firm performance. The commitment to quality and an understanding of supply chain dynamics have great effect on performance. Foster $e t$ al. (2011) conducted a comparative study on how quality tools and methods are adopted by operations and supply chain managers. It was realized that operations and supply chain managers approach quality management differently.

Although manufacturing activities have experienced a steady growth in Tanzania, the quality of industrial products is still low. This is because the best practices of quality management are not well implemented (MITM, 2010). The main purpose of this study was to evaluate the extent of quality management tools and methods as well as performance of Tanzania's manufacturing industries and then correlate the practices and performance. This will help to expose the strengths and weaknesses in quality management that can be worked out in order to improve the performance and meet the customer expectations.

\section{METHODS AND MATERIALS}

Seventy-eight (78) manufacturing industries located in Dar es Salaam region were randomly surveyed to collect data using questionnaires. The survey focused on nine categories of manufacturing industries namely basic metal; food, beverage and tobacco; textiles and clothing; wood and wooden products; paper and paper products; chemical, petroleum, rubber and plastics; nonmetallic mineral; fabricated metal, machinery and equipment; and other manufacturing industries. The questionnaires contained both single-item questions and multi-item questions. In single-item questions, general information on the status of manufacturing industries was captured. Quality management practices (QMP) and manufacturing performance (MP) were operationalized into items. QMP had 13 items including use of benchmarking; six sigma; inspection; quality circles; seven basic tools; simplify the products; using standard componets; process improvement; design of quality into the products; training in quality management and control; modular design of component parts; considering of quality of raw materials from supplier and top management involvement in quality goals. MP had eight items which are market growth; sales growth; profit growth; customer satisfaction; overall competitive advantage; flexibility in changing the production volume; overall product quality and delivery speed. The variables formed multiple-item questions that were measured using a five-point Likert scale.

Descriptive statistics, reliability analysis, factor analysis and correlation analysis were performed using SPSS 20 software package. Descriptive statistics quantified the frequency distributions, means and standard deviations of QMP and MP items. Cronbach's alpha was employed to analyse the reliability or internal consistency of the items. The alpha coefficient ranges in value from 0 to 1 and the higher the value the more reliable is the variable. Primarily, the acceptable reliability of the variable is measured by the alpha coefficient greater than 0.6. Factor analysis was used to identify underlying factors that explain the pattern of correlations within a set of observed variables. In this case, a small number of factors that explain most of the variance that is observed in a much larger number of variables can be identified. Correlation analysis was then conducted to determine the link between the underlying factors of 
quality management practices and those of manufacturing performance in order to quantify the effect of quality management practices on the performance of manufacturing industries.

\section{RESULTS AND DISCUSSION}

Among 78 industries surveyed, $59(75.6 \%)$ industries were private owned, 15 (19.2\%) belonged to the Government while only 4 $(5.1 \%)$ were parastatal industries as shown in Figure 1. These results illustrate that most of manufacturing industries in Tanzania are owned by private companies. This is due to the implementation of the privatisation policy in the early 1990s whereby most of public-owned manufacturing industries were sold to private investors aiming at improving their capacity to compete in the markets. In addition, the attitude of individuals or groups of people to become entrepreneurs increased the number of private industries in the country.

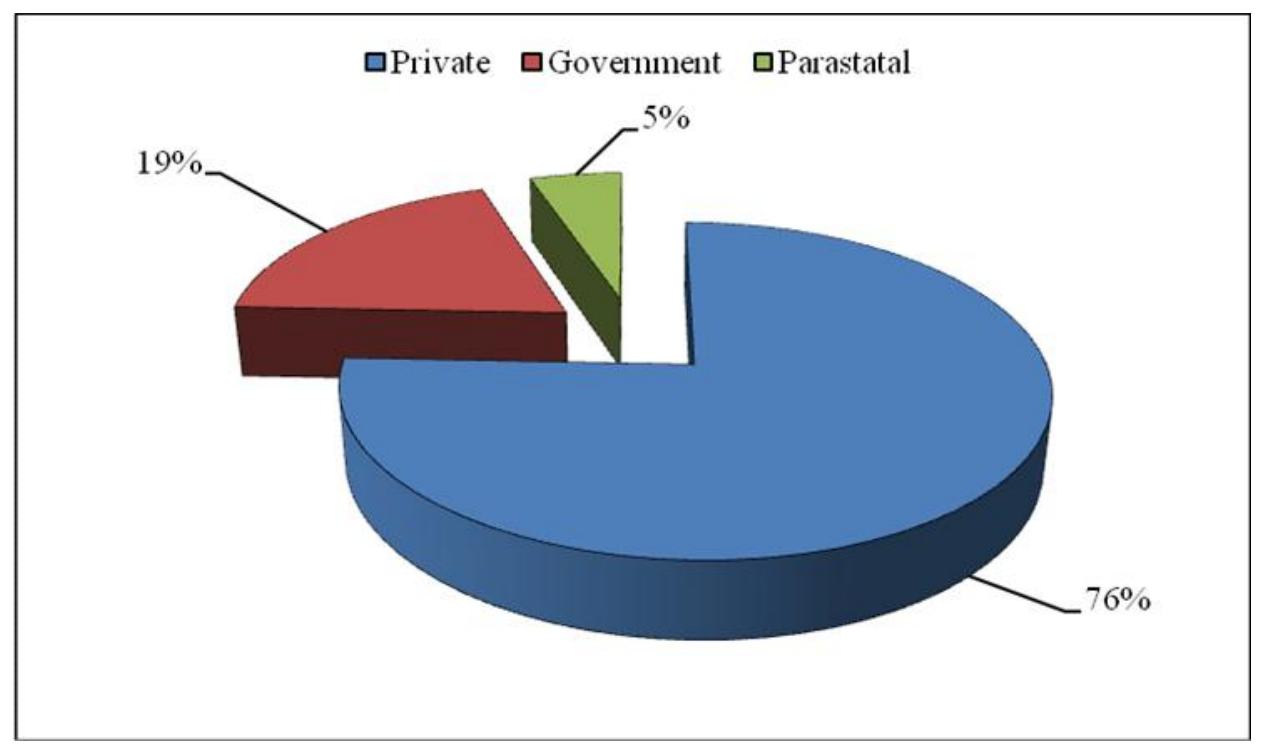

Figure 1: Distribution of industries by ownership

The surveyed manufacturing industries possessed different ranges of the number of employees as shown in Table 1. The number of employees ranged from 1 to 350 with 21 industries (26.9\%) having employees ranging from 101 to 150 . This range had the highest total number of employees recording to 2552. This was followed by 9 industries with employees ranging between 201 and 250 with a total of 2037 employees. Eighteen industries (23\%) had the range between 1 and 50 employees with the least total number of employees amounting to 426. In the context of Tanzania, the scales of manufacturing industry are categorised as follows (MIT, 2002); micro industry comprises 1-4 employees or may have capital investment in machinery of up to TZS 5 million; small industry with 5-49 employees or capital investment of above 5 million to 200 million; medium industry comprises 50-99 employees or capital investment of above 200 million to 800 million; and large industry with 100 employees and more or capital investment of above 800 million. Based on the findings on the number of employees, it is obvious that the range with few employees $(4.2 \%)$ is related to micro- and smallscaled industries. On the other hand, large industries have employed a significant number of employees (86.6\%); indicating that most of manufacturing industries are large in scale. The rest percentage of 
employees (9.2\%) is apportioned for medium-scale industries.

Figure 2 shows the distribution of the surveyed industries by their manufacturing categories. Industries dealing with food, beverage and tobacco products are highly represented $(22 \%)$ followed by industries in production of chemical, petroleum, rubber and plastic products $(19 \%)$. It can be argued that products from these two manufacturing categories have penetrated into the market and continue to perform well.

Table 1: Range of employees in surveyed industries

\begin{tabular}{|c|c|c|}
\hline Range of employees & Number of industries & Total number of employees \\
\hline $1-50$ & 18 & 426 \\
\hline $51-100$ & 12 & 919 \\
\hline $101-150$ & 21 & 2552 \\
\hline $151-200$ & 10 & 1794 \\
\hline $201-250$ & 9 & 2037 \\
\hline $251-300$ & 5 & 1348 \\
\hline $301-350$ & 3 & 948 \\
\hline Total & $\mathbf{7 8}$ & $\mathbf{1 0 0 2 4}$ \\
\hline
\end{tabular}

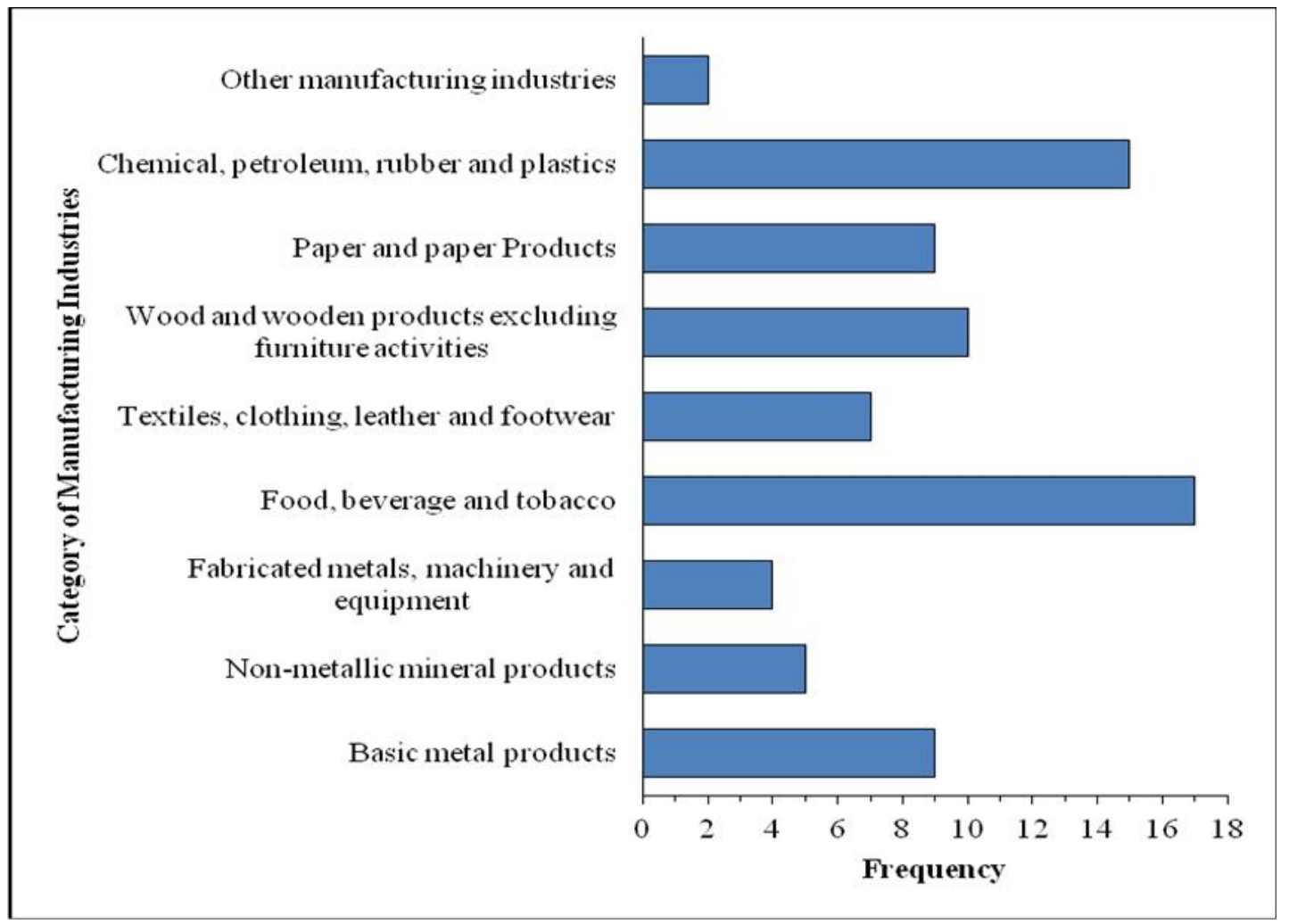

Figure 2: Distribution of industries by manufacturing category

The thirteen items that measured QMP captured Cronbach's alpha of 0.88 . This value is greater than 0.6 indicating that all items were consistent and reliable. In addition, all items had communalities greater than 0.5 and were maintained for 
further factor analysis. The overall mean and standard deviation of QMP variables are summarized in Table 2. As noted in the table, most of the variables are on the right of the five-point Likert scale indicating favorable implementation of quality management tools and methods by local manufacturing industries. Only one item (Six Sigma) is on the left of the scale reflecting that manufacturing industries rarely implement this tool. The standard deviations for the variables do not significantly differ denoting that the spread of the data was about the same. From these results, it can be deduced that manufacturing industries are likely to become stronger to penetrate into market competition if they devote their efforts to implementing quality management tools and methods.

\section{Table 2: Summary of item statistics for QMP}

\begin{tabular}{|l|l|c|c|}
\hline No. & Items/variables & Mean & Std. Deviation \\
\hline 1 & Benchmarking & 3.04 & 1.025 \\
\hline 2 & Six Sigma & 2.72 & 1.183 \\
\hline 3 & Inspection & 3.67 & 0.921 \\
\hline 4 & Quality circles & 3.26 & 1.050 \\
\hline 5 & Seven basic quality tools & 3.58 & 0.845 \\
\hline 6 & Simplify the products & 3.23 & 0.939 \\
\hline 7 & Using standard components & 3.29 & 1.033 \\
\hline 8 & Process improvement & 3.51 & 0.977 \\
\hline 9 & Design of quality into products & 3.18 & 1.003 \\
\hline 10 & Training in quality management and control & 3.13 & 0.917 \\
\hline 11 & Modular design of component parts & 3.27 & 0.921 \\
\hline 12 & Considering quality of raw material from supplier & 3.47 & 1.053 \\
\hline 13 & Top management involvement in quality goals & 3.65 & 1.055 \\
\hline
\end{tabular}

The eight items that measured MP captured Cronbach's alpha of 0.84 . This value is greater than 0.6 indicating that all variables were consistent and reliable. Two items namely gross profit growth and delivery speed had small communalities of less than 0.4. They were dropped, but yet maintaining the same Cronbach's alpha value. The overall mean and standard deviation of MP items are summarised in Table 3. All the items are on the right of the five-point Likert scale indicating favourable manufacturing performance. The spread of the standard deviations was uniform. This is a sign that manufacturing industries are expected to perform better to win competitive advantage.
Factor analysis was implemented to reduce the QMP and MP scale items into underlying factors obtained by clustering related items/variables into fewer dimensions than the origin items/variables. The principal component analysis (PCA) and varimax rotation with Kaiser Normalization were used to obtain the results for the factor analysis. As for QMP and based on eigenvalues greater than 1 , the first four factors formed the extracted solution explaining $72.7 \%$ of the variability in the thirteen original items. The rotated solution maintained $72.7 \%$ of the variability in the variables, but the variation is spread more evenly over the factors. It means that the four extracted factors can represent the thirteen items with only $27.3 \%$ loss of information. The 
four rotated factors with their factor

loadings are presented in Table 4.

Table 3: Summary of item statistics for MP

\begin{tabular}{|l|l|c|c|}
\hline No. & Items/variables & Mean & Std. Deviation \\
\hline 1 & Sales growth & 3.63 & 0.605 \\
\hline 2 & Market share growth & 3.45 & 1.015 \\
\hline 3 & Gross profit growth & 3.13 & 0.888 \\
\hline 4 & Customer satisfaction & 3.54 & 0.976 \\
\hline 5 & Overall competitive position & 3.56 & 0.676 \\
\hline 6 & Flexibility in changing to different production volume & 3.12 & 1.057 \\
\hline 7 & Overall product quality & 3.53 & 0.963 \\
\hline 8 & Delivery speed & 3.41 & 0.711 \\
\hline
\end{tabular}

Table 4: Rotated matrix with factor loading of QMP items

\begin{tabular}{|c|l|c|c|c|c|}
\hline \multirow{2}{*}{ No. } & Items/variables & \multicolumn{3}{|c|}{ Factors } \\
\cline { 2 - 5 } & & 1 & 2 & 3 & 4 \\
\hline 1 & Benchmarking & -0.156 & 0.492 & 0.475 & 0.273 \\
\hline 2 & Six Sigma & 0.046 & 0.185 & 0.788 & 0.146 \\
\hline 3 & Inspection & 0.597 & 0.411 & 0.063 & 0.239 \\
\hline 4 & Quality circles & 0.353 & 0.221 & 0.053 & 0.805 \\
\hline 5 & Seven basic quality tools & 0.659 & 0.200 & 0.262 & 0.305 \\
\hline 6 & Simplify the products & 0.313 & 0.244 & 0.608 & 0.165 \\
\hline 7 & Using standard components & 0.852 & 0.046 & 0.075 & 0.193 \\
\hline 8 & Process improvement & 0.699 & 0.191 & 0.477 & -0.048 \\
\hline 9 & Design of quality into products & 0.342 & 0.787 & 0.053 & 0.021 \\
\hline 10 & Training in quality management and control & 0.385 & 0.135 & 0.724 & 0.055 \\
\hline 11 & Modular design of component parts & 0.122 & 0.063 & 0.232 & 0.853 \\
\hline 12 & Considering quality of raw material from supplier & 0.096 & 0.801 & 0.258 & 0.065 \\
\hline 13 & Top management involvement in quality goals & 0.197 & 0.784 & 0.295 & 0.227 \\
\hline
\end{tabular}

With respect to MP, the first two factors formed the extracted solution explaining $74 \%$ of the variability in the six items (two items were dropped due to their lower communalities). The rotated solution captured $74 \%$ of the variability in the variables but the variation is spread more evenly over the factors (Table 5). This means that the two extracted factors can represent the six items with only $26 \%$ loss of information.

For the purpose of preserving convergence and discriminant validity, only items of QMP and MP with factor loading greater than 0.5 and have no loading exceeding 0.4 on the second factor were retained (Kannan and Tan, 2005). Thus, the four factors in QMP can be expressed as shown in Table 6. Factor 1 includes two items namely basic quality tools and standard components which relate to quality conformity using basic quality tools and standard components. Factor 2 is captured with three items including design of quality into products, considering quality of raw material from supplier and involvement of top management in quality goals. These items are related to quality commitment in the supply chain including quality raw materials from suppliers and quality finished products to end-users. Factor 3 has three items which are six sigma, simplicity of products and training in quality management and control. This factor is gauged with quality knowledge of 
product design as well as process control. Lastly, factor 4 is confined with two items specifically quality circles and modular design of component parts. This factor is much related to discussion and decision within groups for quality improvement of modular designs.

Table 5: Rotated matrix with factor loading of MP items

\begin{tabular}{|c|l|c|c|}
\hline \multirow{2}{*}{ No. } & Items/variables & \multicolumn{2}{|c|}{ Factors } \\
\hline 1 & Sales growth & 0.076 & 0.925 \\
\hline 2 & Market share growth & 0.398 & 0.786 \\
\hline 3 & Customer satisfaction & 0.868 & 0.227 \\
\hline 4 & Overall competitive position & 0.747 & 0.343 \\
\hline 5 & Flexibility in changing to different production volume & 0.853 & 0.086 \\
\hline 6 & Overall product quality & 0.746 & 0.168 \\
\hline
\end{tabular}

Table 6: QMP factors and their factor loading

\begin{tabular}{|c|l|l|c|}
\hline No. & Factor & Item/variable & Factor loading \\
\hline \multirow{2}{*}{1} & \multirow{2}{*}{ QMP1: Conformance quality } & Seven basic quality tools & 0.659 \\
\cline { 3 - 4 } & & Using standard components & 0.852 \\
\hline 2 & \multirow{2}{*}{ QMP2: Quality commitment } & Design of quality into products & 0.787 \\
\cline { 3 - 4 } & & Considering quality of raw material from supplier & 0.801 \\
\cline { 3 - 4 } & & Top management involvement in quality goals & 0.784 \\
\hline \multirow{2}{*}{3} & \multirow{2}{*}{ QMP3: Quality knowledge } & Six Sigma & 0.788 \\
\cline { 3 - 4 } & & Q Simplify the products & 0.608 \\
\cline { 3 - 4 } & & Training in quality management and control & 0.724 \\
\hline
\end{tabular}

Table 7: MP factors and their factor loading

\begin{tabular}{|c|c|c|c|}
\hline No. & Factor & Item/variable & Factor loading \\
\hline \multirow[t]{4}{*}{1} & \multirow{4}{*}{$\begin{array}{l}\text { MP1: } \\
\text { Operational performance }\end{array}$} & Customer satisfaction & 0.868 \\
\hline & & Overall competitive position & 0.747 \\
\hline & & Flexibility in changing to different production volume & 0.853 \\
\hline & & Overall product quality & 0.746 \\
\hline \multirow[t]{2}{*}{2} & \multirow{2}{*}{$\begin{array}{l}\text { MP2: } \\
\text { Financial performance }\end{array}$} & Sales growth & 0.925 \\
\hline & & Market share growth & 0.786 \\
\hline
\end{tabular}

On the other hand, the two factors in MP can be expressed as shown in Table 7 . Factor 1 includes four items which are customer satisfaction, overall competitive position, flexibility in production volume and overall product quality. These items highly relate to non-financial (operational) performance whereby the performance is not measured in terms of money value. Factor 2 comprises two items which are sales growth and market share growth directly related to financial performance.

A correlation analysis was conducted to determine the relationship between the factors of quality management practices and those of manufacturing performance. Table 8 describes the relationship among four QMP factors and two MP factors. Using a cut-off value of 0.5 as an average correlation coefficient, quality 
commitment has shown to have the highest impact on operational performance. This finding is an indication of the importance of quality commitment by the top management in the supply chain from suppliers of raw materials through endusers of finished products supporting customer satisfaction, competitive advantage, flexibility in production quantity and overall product quality. In addition, conformance quality and quality improvement had very little impact on both operational and financial performance. In addition, most of correlation coefficients between quality management practices and manufacturing performance indicated in Table 8 are relatively small. However, these do not preclude internal initiatives by manufacturing industries to advocate the use of quality management tools and methods for improving the overall performance. Instead, these deficiencies prompt for immediate quality strategic decisions for more improvement.

Table 8: Correlation of QMP and PM factors

\begin{tabular}{|c|c|c|c|c|c|c|c|}
\hline \multirow[t]{2}{*}{$\begin{array}{l}\text { Quality } \\
\text { Indicators }\end{array}$} & \multirow[t]{2}{*}{$\begin{array}{l}\text { Specific } \\
\text { Indicator }\end{array}$} & \multicolumn{4}{|c|}{ Operational performance } & \multicolumn{2}{|c|}{$\begin{array}{c}\text { Financial } \\
\text { performance }\end{array}$} \\
\hline & & $\begin{array}{c}\text { Customer } \\
\text { satisfaction }\end{array}$ & $\begin{array}{c}\text { Competitive } \\
\text { Position }\end{array}$ & $\begin{array}{l}\text { Flexibility } \\
\text { in volume }\end{array}$ & $\begin{array}{l}\text { Product } \\
\text { quality }\end{array}$ & $\begin{array}{l}\text { Sales } \\
\text { growth }\end{array}$ & $\begin{array}{l}\text { Market } \\
\text { growth }\end{array}$ \\
\hline \multirow[b]{2}{*}{$\begin{array}{l}\text { Conformance } \\
\text { quality }\end{array}$} & $\begin{array}{l}\text { Seven Basic } \\
\text { Quality Tools }\end{array}$ & $0.248^{*}$ & $0.241^{*}$ & $0.332^{* *}$ & $0.324^{* *}$ & 0.145 & 0.103 \\
\hline & $\begin{array}{l}\text { Using } \\
\text { Standard } \\
\text { components }\end{array}$ & $0.240^{*}$ & $0.424^{* *}$ & $0.230^{*}$ & $0.286^{*}$ & $0.261^{*}$ & 0.132 \\
\hline \multirow{3}{*}{$\begin{array}{l}\text { Quality } \\
\text { commitment }\end{array}$} & $\begin{array}{lr}\text { Design of } \\
\text { Quality into } \\
\text { products }\end{array}$ & $0.682^{* *}$ & $0.596^{* *}$ & $0.495^{* *}$ & $0.452^{* *}$ & 0.218 & $0.379^{* *}$ \\
\hline & $\begin{array}{l}\text { Quality of } \\
\text { Raw Material } \\
\text { from supplier }\end{array}$ & $0.645^{* *}$ & $0.695^{* *}$ & $0.662^{* *}$ & $0.404^{* *}$ & $0.341^{* *}$ & $0.454^{* *}$ \\
\hline & $\begin{array}{l}\text { Involvement } \\
\text { in Quality } \\
\text { goals }\end{array}$ & $0.612^{* *}$ & $0.587^{* *}$ & $0.677^{* *}$ & $0.539^{* *}$ & $0.264^{*}$ & $0.523^{* *}$ \\
\hline \multirow{3}{*}{$\begin{array}{l}\text { Quality } \\
\text { knowledge }\end{array}$} & Six Sigma & $0.381^{* *}$ & 0.218 & 0.182 & 0.200 & $0.504^{* *}$ & $0.366^{* *}$ \\
\hline & $\begin{array}{l}\text { Simplify the } \\
\text { Products }\end{array}$ & $0.316^{* *}$ & 0.222 & $0.353^{* *}$ & 0.108 & $0.519^{* *}$ & $0.408^{* *}$ \\
\hline & $\begin{array}{l}\text { Training in } \\
\text { Quality } \\
\text { management } \\
\text { and Control }\end{array}$ & 0.169 & $0.259^{*}$ & 0.159 & -0.018 & $0.344^{* *}$ & 0.161 \\
\hline \multirow[b]{2}{*}{$\begin{array}{l}\text { Quality } \\
\text { improvement }\end{array}$} & $\begin{array}{l}\text { Quality } \\
\text { Circles }\end{array}$ & $0.256^{*}$ & 0.196 & $0.254^{*}$ & $0.263^{*}$ & 0.111 & $0.281^{*}$ \\
\hline & $\begin{array}{l}\text { Modular } \\
\text { Design of } \\
\text { Component } \\
\text { Parts }\end{array}$ & 0.140 & 0.191 & $0.288^{*}$ & 0.204 & -0.028 & 0.064 \\
\hline
\end{tabular}

** Correlation is significant at the 0.01 level (2-tailed)

*Correlation is significant at the 0.05 level (2-tailed)

\section{CONCLUSIONS}

This study has analyzed the extents of quality management practices and manufacturing performance as well as the linkage between the practices and performance. On the basis of the findings, it was found that $86.6 \%$ of surveyed 
manufacturing industries are large in scale. There is a need to boost small-scale industries because they are more effective in utilizing local resources using simple and affordable technologies. Industries dealing with food, beverage and tobacco products represent $22 \%$ of manufacturing industries followed by industries in production of chemical, petroleum, rubber and plastic products representing $19 \%$. Necessary measures are required to also enhance metal industries because they act as catalysts to spark development in other sectors such as agriculture, transport, mining, energy and domestic consumer goods. Such measures should go in line with acquiring modern production machinery such as computer numerical control (CNC) machines thus adapting to new production technologies. The extents of quality management practices and manufacturing performance are above average, that is, more than 3 points of Likert Scale except for Six Sigma variable. Manufacturing industries should put into effect these strengths in order to produce high-quality products and penetrate into the global market. Quality commitment significantly correlates with both operational and financial performance with correlation coefficients above 0.5. Thus, enforcement on the implementation of quality management tools and methods is required to help manufacturing industries to improve their performance and win the competitive advantage. However, the correlation coefficients are somewhat small for other variables, and as such, necessary quality management options should be taken so that the manufacturing performance can be reasonably improved.

\section{REFERENCES}

Adam E.E., Flores B.E. and Macias A. (2001). Quality improvement practices and the effect on manufacturing firm performance: Evidence from Mexico and the USA, International Journal of Production Research, $39(1)$ : 43-63. https://doi.org/10.1080/00207540150208853
Confederation of Tanzania Industries and Confederation of Danish Industries (CTI/DI) (2000). The manufacturing sector in Tanzania, Final Report.

Foster S.T., Wallin C. and Ogden J. (2011). Towards a better understanding of supply chain quality management practices, International Journal of Production Research, $\quad 49(8)$ : 2285-2300. https://doi.org/10.1080/00207541003733791

Jaafreh A.B. (2013). The effect of quality management practices on organizational performance in Jordan: An empirical study, International Journal of Financial Research, 4(1):

93-109.

DOI: https://doi.org/10.5430/ijfr.v4n1p93

Kannan V.R. and Tan K.C. (2005). Just in time, total quality management, and supply chain management: Understanding their linkages and impact on business performance, Omega The International Journal of Mangement Science, 33: 153162. doi: 10.1016/j.omega.2004.03.012

Keinan A.S. and Karugu J. (2018). Total quality management practices and performance of manufacturing firms in Kenya: Case of Bamburi Cement Limited, International Academic Journal of Human Resource and Business Administration, 3(1): 81-99. Available online at http://www.iajournals.org/articles/iajhrba_v 3_i1_81_99.pdf

Kuei C-H, Madu C.N. and Winch J.K. (2008). Supply chain quality management: A simulation study, Information and Management Sciences, 19(1): 131-151.

Lin C., Chow W.S., Madu C.N., Kuei C-H. and Yu P.P. (2005). A structural equation model of supply chain quality management and organizational performance, International Journal of Production Economics, 96: 355365. doi: 10.1016/j.ijpe.2004.05.009

Ministry of Industry and Trade of Tanzania (MIT) (2002). Small and medium enterprise development policy, Ministry Report, Dar es Salaam, Tanzania.

Ministry of Industry and Trade of Tanzania (MIT) (2001). Sustainable industrial development and competitiveness (analysing competitiveness, strategies, 
policies and action plan to accelerate development), Ministry Report, Dar es Salaam, Tanzania.

Ministry of Industry, Trade and Marketing (MITM) (2010). Tanzania annual survey of industrial production and performance, Statistical Report, Dar es Salaam, Tanzania.

Nguyen M.H., Phan A.C. and Matsui Y. (2018). Contribution of quality management practices to sustainability performance of Vietnamese industry, Sustainability, 10: 375 , $1-31$. https://doi.org/10.3390/su10020375

Sabella A., Kashou R. and Omran O. (2014). Quality management practices and their relationship to organisation performance, International Journal of Operations and Production Management, 34(12): 14871505. DOI: 10.1108/IJOPM-04-2013-0210

Santos-Vijande M.L. and Alvarez-Gonzalez L.I. (2007). TQM and firms performance: An EFQM excellence model research based survey, International. Journal of Business
Science and Applied Management, 2(2): 2141.

Sayyad N. (2017). The relationship between total quality management practices and their effects in firm's performance, Business and Entrepreneurship Journal, 6(2): 35-51.

Talib F., Rahman Z. and Qureshi M.N. (2010). Integrating total quality management and supply chain management: Similarities and benefits, Journal of Information Technology and Economic Development, 1(1): 53-85.

Vanichchinchai A. and Igel B. (2011). The impact of total quality management on supply chain management and firm's supply performance, International Journal of Production Research, 49(11): 3405-3424. DOI: $10.1080 / 00207543.2010 .492805$

Zakuan N.M., Yusof S.M. and Shamsudin S. (2007). Implementation of quality management practices in Malaysian automotive industries: A review, Regional Conference on Engineering Mathematics, Mechanics, Manufacturing and Architecture, 105-116. 